\title{
CONTRIBUTION OF SIMPLE HYDROGEOLOGICAL INDICATING METHODS IN CONTAMINATION-IMPACTED ENVIRONMENTS
}

\author{
UPORABA METODE PREPROSTIH HIDROGEOLOŠKIH \\ INDIKATORJEV V ONESNAŽENIH OKOLJIH
}

\author{
Slavomír MIKITA ${ }^{1} \&$ Vladimír VYBÍRAL ${ }^{2}$
}

\begin{abstract}
UDC 556.3:504

Slavomír Mikita \& Vladimír Vybíral: Contribution of simple hydrogeological indicating methods in contamination-impacted environments

Under the project of Ministry of the environment of Slovak Republic a "real" impact of various contaminant sources on water was monitored and assessed during the period of 4 years. Various geological environments of The Western Carpathians were chosen as studying areas. The results of the project confirm that the influence of the contamination source is variable in space and time. An amount of objective and efficient information is necessary to fulfill the requirements for the water treatment The possibility how to minimize the amount of expensive and intricate methods used by investigation was to connect them with hydrogeological indicating methods (HIM). The correlated relations distinguished between contaminant and physical characteristics of water allow using the obtained local information in larger area and repeating them in higher frequency. The economical benefit is relative to increasing demands on space and time. The base was built on the water conductivity and water temperature measurements set in field. The measured values which were processed basically allow obtaining indirect information about the contamination spreading. By correlation the values with water analyses for a monitoring site from specific studied locality and by added other information from field methods the results can be amplified. It is possible to substitute the intricate and expensive contaminant spreading mapping methods by HIM and monitor the dynamic changes of contamination influences in space and time with denser data net.
\end{abstract}

Key words: contamination, environment, conductivity, water temperature, information.

Izvleček

UDK 556.3:504

Slavomír Mikita \& Vladimír Vybíral: Uporaba metode preprostih hidrogeoloških indikatorjev $v$ onesnaženih okoljih $\mathrm{V}$ okviru projekta slovaškega ministrstva za okolje, smo v obdobju štirih let izvajali raziskave vpliva različnih virov onesnaževal na vodne vire. Izbrali smo več področij z različno geološko sestavo v zahodnih Karpatih . Rezultati so potrdili, da je vpliv virov onesnaženj spremenljiv v prostoru in času, zato učinkovita zaščita vodnih virov zahteva veliko prostorsko in časovno gostoto informacij in raziskav. Da bi pri tem zmanjšali uporabo dragih in zapletenih metod, smo uporabili metodo hidrogeoloških indikatorjev (HIM), ki temelji na osnovi povezave med koncentracijo onesnaževal in osnovnimi fizikalnimi parametri vode, kot sta temperatura in specifična električna prevodnost. Merjenje teh parametrov omogoča posredno zaznavanje onesnaževal. Če njihovo zvezno opazovanje združimo s točkovnimi analizami vode in ostalimi terenskimi metodami, lahko vzpostavimo učinkovito in cenovno ugodno kartiranje širjenja onesnaževal.

Ključne besede: onesnaževanje, okolje, specifična električna prevodnost, temperatura vode, informacije.

\footnotetext{
${ }^{1}$ Department of hydrogeology, Faculty of Natural Sciences, Comenius University Bratislava, Mlynská dolina, Slovak Republic; e-mail:mikita@fns.uniba.sk

2 Nobelova 34, 83102 Bratislava, Slovak Republic.
}

Received/Prejeto: 18.09.2006 


\section{INTRODUCTION}

The requirements for water quality protection have a very high priority. To protect the water contamination must be clearly detected, considered and predicted. Specific localities were studied with aim to improve knowledge about transport of contaminants and behaving the contamination-impacted environments.

Contamination-impacted environments in this case can be characterized as localities where the source of contamination has an influence on their vicinity with significant changes in water quality. The most common kind of contamination-impacted environments in Slovak Republic present an "old" landfills often built without legislative control and sufficient information about the waste storage. Under the project of Ministry of the Environment of Slovak Republic a "real" impact of 15-selected landfills on specific geological setting of The Western Carpathians was studied during the period of 4 years (Vybíral et al., 2005).

In "old" landfills where all types of materials have been deposited and are possible source of various kinds of organic and inorganic pollutants, originated in leaching process. Landfill leachate is generated by excess rainwater percolating through the waste layers. Combined physical, chemical and microbial processes in the waste transfer pollutants from the waste materials to the percolating water. Focusing on the common type of landfill receiving a mixture of municipal, commercial and mixed industrial waste, but excluding significant amounts of concentrated specific chemical waste, landfill leachate may be characterized as water based solution of four groups of pollutants (Christensen et al., 2001).

- Dissolved organic matter, expressed as Chemical Oxygen Demand (COD) or Total Organic C (TOC), including $\mathrm{CH}_{4}$, volatile fatty acids and more refractory compounds for example, fulvic-like and humic-like compounds,

- Inorganic macrocomponents: $\mathrm{Ca}, \mathrm{Mg}, \mathrm{Na}, \mathrm{K}$, $\mathrm{NH}_{4}^{+}, \mathrm{Fe}, \mathrm{Mn}, \mathrm{Cl}, \mathrm{SO}_{4}^{2+}, \mathrm{HCO}_{3}^{-}$,

- Heavy metals: $\mathrm{Cd}, \mathrm{Cr}, \mathrm{Cu}, \mathrm{Pb}, \mathrm{Ni}$ and $\mathrm{Zn}$,

- Xenobiotic organic compounds (XOCs) originated from household or industrial chemicals are present in relatively low concentrations in the leachate (usually less than $1 \mathrm{mg} / \mathrm{l}$ of individual compounds). These compounds include among others a variety of aromatic hydrocarbons, phenols and chlorinated aliphatics.

Other compounds may be found in leachate from landfills: e.g. B, As, Se, Ba, Li, $\mathrm{Hg}$ and $\mathrm{Co}$. But in general these compounds are found in very low concentrations and are only of secondary importance.
Leachate composition varies significantly among landfills depending on waste composition, waste age and landfilling technology.

Where leachate enters the groundwater, significant changes in water quality are observed and complicated biogeochemical patterns develop in the leachate pollution plume.

The fate and behaving of contaminants will depend on many factors, like individual characters of contaminants or hydrogeological conditions of given environment. In this system various chemical, biochemical and physical processes are running and the chemical equilibrium is changing. One of the main characteristic manifestations related to the contaminants spreading from the landfill is the presence a sequence of redox zones in the groundwater. They originated from leachate reducing processes with methanogenic conditions close to the landfill and oxidized conditions in the outskirts of the plume.

The aim of the project was also to present the optimal methods for investigation and monitoring of the contaminant spreading in specific environments. From the view of contamination spreading mapping and monitoring is necessary to get information about (Šráček et al., 2000):

- nature of the contaminants, source and way of contamination,

- area and rate of contamination, including the background values that are valid for specific localities,

- migration parameters, direction and velocity of contamination spreading, characteristics of the contaminated environment (porosity, granularity), hydrogeological parameters, groundwater regime,

- history of contamination and its development in time, trends of contamination differences,

- evaluation of the objects endangered by contamination spreading, the level of their endangerment, the necessity and propose of remediation methods.

To get answers to most of these questions is only possible by studying the interaction zone - the zone of real influence of the source of contamination on their vicinity (Fig. 1).

Zone of interaction is dynamic in space and time; it depends on the water regime, the characteristics of landfill material, the maturity of stored material and engineering geological and hydrogeological conditions.

For the approach to solve the project it was useful to distinguish the landfills due their characteristic zone of interactions with aquatic environment (Putiška et al., 2005). Four main models of landfills can by presented: a) model with zero thickness of superincumbent bed (or 


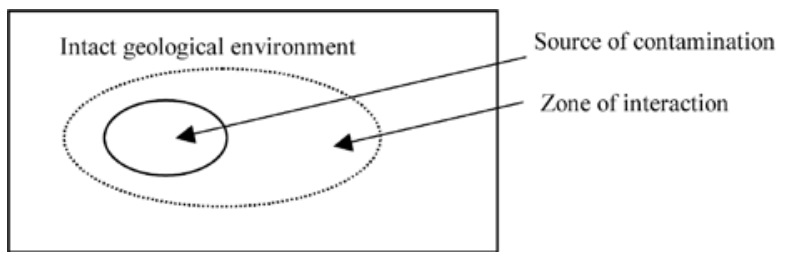

Fig. 1: Model of interaction.

landfills of "valley type"), b) model with the impermeable subsoil in 10-14 m depth, c) model with impermeable subsoil in „endless” depth, d) model of landfill encapsulated by slurry trench walls.

For the landfill locallizated on karst the model with impermeable subsoil in "endless” depth can be applied. In this case landfill is deposited directly on the permeable environment; vertical movement of groundwater is unlimited. Landfill material is deposited into natural or artificial depressions, as well as, onto the natural surface. Contamination is carried out from the landfill by infiltrating rainwater. The groundwater table is usually too deep for effective observation by boreholes and another methods are focusing on natural objects in the landfill vicinity (springs, rivers) therefore more suitable. Relative big differences of water quality in seasonal variations can be observed. Only one locality (DNV - Srdce) was situated on karst but obtained knowledge correspond well with the experiences from other countries, f. e. Slovenia (Petrič \& Šebela, 2005), Sardinia (personal experience).

\section{HYDROGEOLOGICAL INDICATING METHODS (HIM)}

For the contamination spreading observation information about the water physical-chemical features around the contamination-impacted area are very important. The chemical analyses of water yield accurate information but they are not able to notice effectively frequent changes which depend on the influence of external (precipitation, air temperature) and internal (character and maturing of contamination, geology, hydrogeology) factors. The requirements on monitoring of the groundwater quality around the landfills has long-term duration (several tens years) and therefore demands on finances and expertise are necessary be taken into account.

There is a need for connecting them with simple but effective and operative mapping methods and subsequently getting more information about the contaminant spreading changes.

Presence and form of some typical chemical macrocomponents from landfill leaching in water is changing physical water parameters significantly and those are possible to be measured.

For mapping activities concerning contamination spreading the field measurement of physical parameters proved very well. Two parameters were measured - water conductivity and water temperature, both belong to Hydrogeological Indicating Methods (HIM).

The water conductivity (termed also as electrolytic conductivity - $\kappa$, given in $\mathrm{mS} . \mathrm{m}^{-1}$ ) is an important parameter in water geochemistry. It is a function of ion concentration in solution, their charge number, mobility and temperature. In waters, the contents of which is constituted mostly by inorganic compounds (drink waters, most of the surface- and some of waste water), the water conductivity can be used as the approximate rate of the mineral electrolytes concentration. In the wastewater that contains salts of organic acid and alkali the water conductivity is an approximate rate of the mineral content and organic electrolytes concentration (Pitter, 1999).

The water conductivity was measured:

- as an additional parameter with the targeted water sampling, at which only samples from the selected sampling places were taken, while in other places the orientation data about the range of contamination were obtained only indirectly,

- as a main parameter, when the water conductivity was the only measured parameter,

- continuously along the whole length of the borehole; observed were the changes in water conductivity in a water column.

Typical average values of water conductivity from measuring on specific localities ranged from 72 to 1043 mS.m ${ }^{-1}$ (Fig. 2).

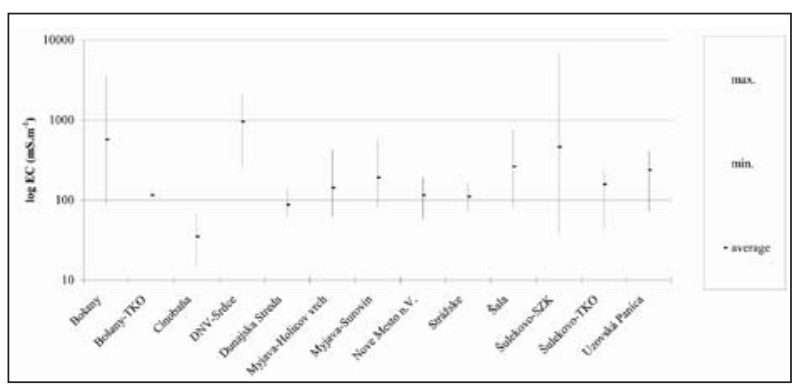

Fig. 2: The water conductivity value differences in the studied localities.

The differences between values were mostly dependent on character of contamination and its maturity, also on geological, hydrogeological and climate conditions. In some of studied localities there was strong influence from seasonality related to the amount of water in the environment (Fig. 3).

As a response there were frequently changing values during the year period. Stability of a frequency was also dependent on the depth of water circulation in the given environment. From the view of a longer time period (several years) the values had a decreasing, or an 


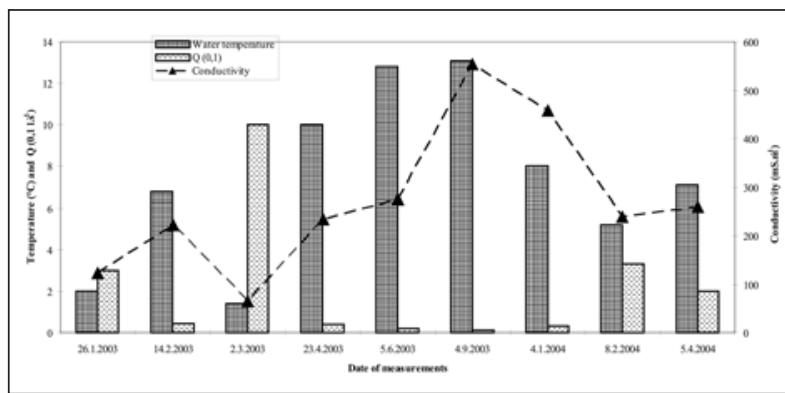

Fig. 3: Cooperation of the conductivity variation in concerning to water temperature and water quantity in one monitoring place of the given locality.

increasing trend, that was connected with the maturity processes in the deposited waste (Fig. 4).

Measuring the water temperature (thermometry) in the field is based on a values contrast. For the purposes of the contamination spreading mapping is depending mostly on the maturity processes in source of contamination where the organic matter is present. The water temperature could reach $40-60{ }^{\circ} \mathrm{C}$. In this way is possible to use it for mapping of transport ways of contamination descending from source.

Water temperature was measured:

- directly in the field with each water sampling,

- for a special purpose, while doing an assessment of the origin of springs and ground water inflows into the streams.

\section{PROCESSING AND EVALUATION OF MEASURED PHYSICAL PARAMETERS}

Information obtained from water conductivity and water temperature measurements was processed basically and also was related to the results of other field methods to be amplified.

The basic processing came from screening all waters accessible in the studied area and it does recur in different time in the same positions. In this way it is possible to:

- assess the relative differences of water features in a studied area,

- map the source of contamination, and distinguish if the contamination is simple, long term, pointed, flatted, etc.,

- map the mass transport paths of contamination,

- estimate the trends of the measured data changes development (Fig. 4),

- detect the changes of the water vertical zonality continuance in the borehole (Fig. 5).

The information obtained according to described way has only relative character and their contribution is mainly by first investigation of the contaminant-impacted environment. The information with higher sig-

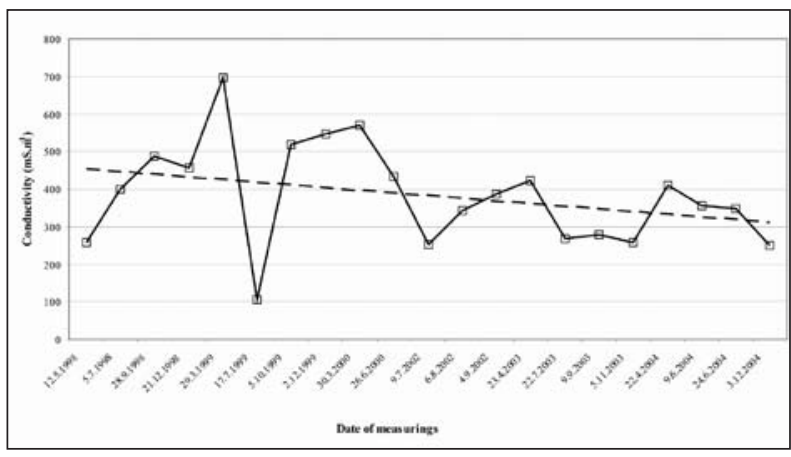

Fig. 4: Water conductivity development during a 6 years period in one of selected monitoring place from given locality.

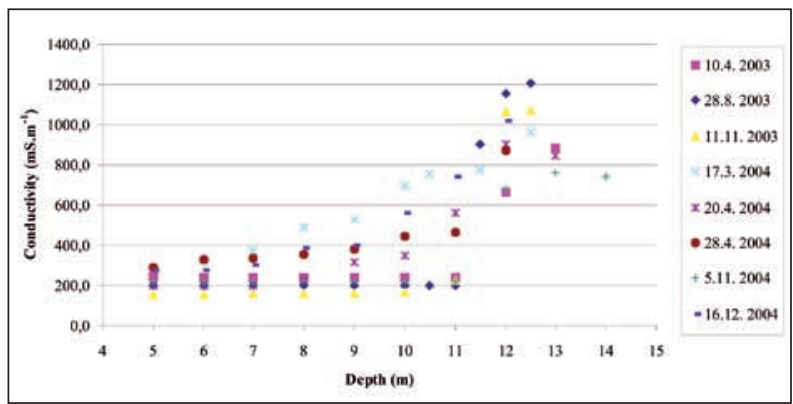

Fig. 5: Manifestation of the conductivity measurements in one borehole from given environment.

nificance about the interactions in system contamination - water environment can be reached by the amplified processing. The amplified processing is based on distinguishing the correlation relations between the electric conductivity and a typical chemical parameter - the macrocontaminant - which is characteristic for the studied area and which we are considering to represent the physical attributes in the given environment. For that purposes the inert chloride affirm very well (Fig. 6).

Finding the optimal correlation relation is conditioned with character of contamination, geological and hydrogeological conditions of given locality. It is therefore necessary to apply the relation on specific monitoring place. The correlation allows substituting the specific chemical component with conductivity measurement and so extending the qualitative point information into space and repeating them in higher frequency. The new information with higher weight for the contamination spreading predictions can be obtained. According to the settings of the impacted environment the achieved information is a good assumption for various purposes:

- to monitor dilution with an increasing distance from the contaminant source (Fig. 7),

- to assess the climate and hydrological influences on contamination (Fig. 3), 


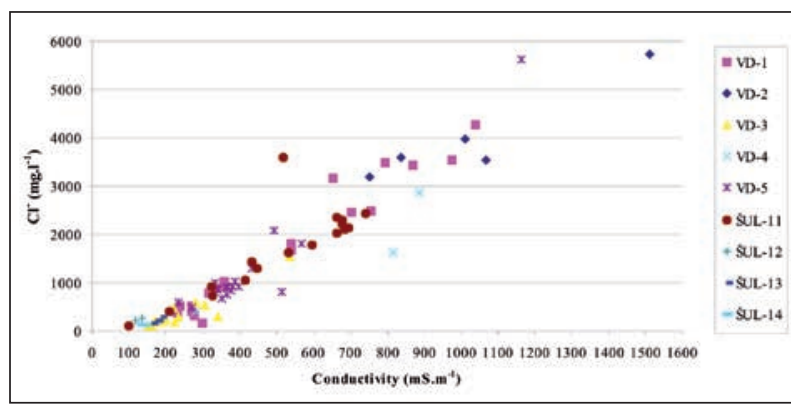

Fig. 6: Dependency between the chloride ions and conductivity from selected monitoring places in one of the studied locality.

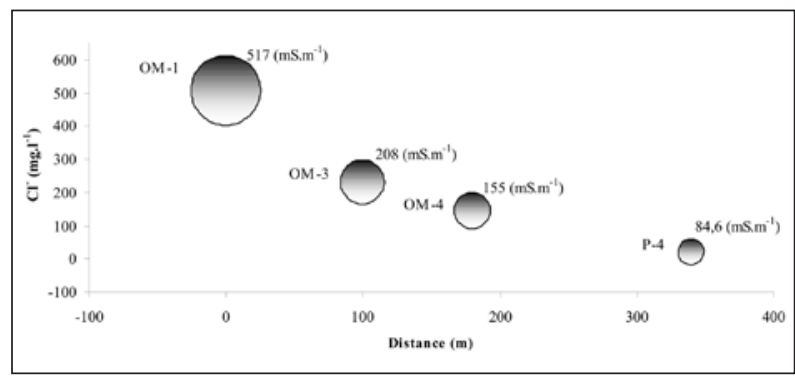

Fig. 7: Expression of a dependency between the parameters of chloride ions, conductivity and distance from contamination source, measured from the monitoring places of given locality.

- to describe the distribution of related components in space and time by developing 3D models (Fig. 8),

- to monitor the intensity and the rate of contamination (Fig 4,7,8),

- to predict the trends of contamination maturing processes (Fig. 3,4,5).

On the Fig. 8 are pointed the values that were detected in 6 boreholes from their water table to the bottom. The boreholes are localized in a front part of given landfill. The main groundwater flow is transverse direction on the boreholes.

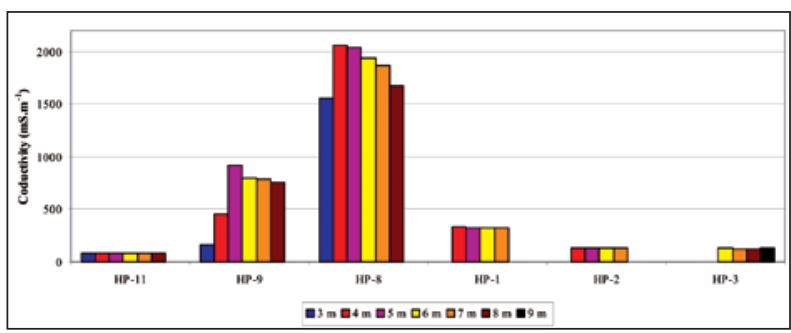

Fig. 8: Water zonality measuring in selected boreholes from one of studied locality.

The results after measuring and processing are possible to interpret also in a form of different outputs (Krčmářr, 2002).

Application of HIM was utilized by dealing with the interaction between contamination-impacted environments and their surroundings with different extent of contribution (Mikita et al., 2005). It is conditioned mainly by hydrogeological conditions of studied environment and the monitoring instruments access to the water. Relatively the best utilization was obtained from a landfill of "valley type" placed to the valley with impermeable or almost impermeable subsoil where the leakage from landfill is distributed to the surrounding area by outflow located in the front parts of landfills (Mikita et al., 2005).

To observing the landfill influence on karst aquatic environment the HIMs can be mainly used for:

- discovering the hidden inflows of contaminants to the rivers, springs or wells present in the vicinity of the landfill,

- continuous monitoring for monitoring points in karst aquifers with caution for unfavorable situation, indirect monitoring of the seasonally differences in water quality.

\section{CONCLUSIONS}

Evaluation of a geological environment and contaminants interference is a complicated problem. The contamination spreading investigation and monitoring requires large amounts of data and detailed information about the surface, groundwater regime, water and soils physical and chemical characteristics. The danger from the given contamination-imapcted environment is radically changing in time and dimensional space. The 15 contamination-impacted areas situated in various geo- logical units of Western Carpathians were analyzed in detail during the four years investigation.

Knowledge had shown that the intricate and expensive methods of mapping of contamination spreading and consequent monitoring can be substituted with simple but effective and operative hydrogeological indicating methods (HIM). Two physical parameters - water conductivity and water temperature were measured directly on monitoring sites. Values obtained from water 
conductivity and water temperature measurements were basically processed and were also related to the results of other field methods to be amplified. Hydrogeological indicating methods in general allow:

- continual monitoring of excessively values changing,

- detection of potentially hidden transfer of contamination into the surface water,

- characterization of the depth of groundwater circulation in studied area,

- repetition of contamination spreading measuring in dimensional space and in time with relatively dense data net,

- monitoring extent and development of the contamination spreading according the changing condition.

The main advantage of HIM is their simplicity and possibility of the directly field measuring which allows sufficient and continual recording of values about the time and dimensional space variations in the contamination development.

The correlated relations between contaminant and water conductivity allow to extend local information from water analyses in larger area and repeating them in higher frequency.

An amount of objective and optimal amount of statistical information for the water protection management requirements can be obtained from HIM. It improves consideration possibilities for prompt answering how the contamination is dangerous, if is necessary to deal with the contamination and how is possible to handle with it in time.

Application of HIM can by utilized with different extent of contribution what is conditioned mainly by hydrogeological conditions of studied environment. For the landfills localized on karst the model with impermeable subsoil in "endless" depth can be applied. The investigation by HIM is here focus mainly on the springs and rivers present in the landfill vicinity.

The economical benefit from using HIM is rising also with the increase requirements on the longtime contamination spreading monitoring and the extent of studied area.

\section{REFERENCES}

Christensen, T.H., Kjeldsen, P., Bjerg, P.L., Jensen D.L., Christensen, J.B., Baun, A., Albrechtsen \& H.-J., Heron, G. 2001: Biogeochemisty of landfill leachate plumes. Applied Geochemistry 16 (2001). 659-718.

Krčmár̆, D., 2002: Moderné výpočtové aplikácie v hydrogeológii.- VÚVH, p. 80, Bratislava.

Mikita, S., Némethy, P. \& Vybíral, V., 2005: New knowledge about contamination spread from the landfills of "valley type".- Podzemná voda. 11, 1, 104-112, Bratislava.

Petrič, M. \& Šebela, 2005: Hydrogeological research as a basis for the preparation of the plan of monitoring groundwater contamination - a case study of the Stara vas landfill near Postojna (SW Slovenia). - Acta carsologica, 2005, 34/2, 489-505, Ljubljana.
Pitter, P., 1999: Hydrogeochemie.- VŠCHT, p. 568, Praha.

Putiška, R., Mojzeš, A., Bednárik, M., Matys, M. \& Vybíral, V., 2005: Geological models of landfills in Slovakia. Contributions to Geophysics and Geodesy.35, 4, 429-439. Bratislava.

Šráček, O., Datel, J., \& Mls, J., 2000: Kontaminační hydrogeologie.- UK, p. 210, Praha.

Vybíral, V., Gajdoš, V., Matys, M. \& Némethyová, M., 2005: Monitorovanie vplyvu enviromentálnych zátaží na geologické činitele životného prostredia vo vybraných regiónoch Západných Karpát - záverečná správa úlohy, Sensor spol. s r.o., p. 109, Bratislava. 